UDC 130.3

DOI https://doi.org/10.30970/PPS.2021.34.2

\title{
"HEART" AS A BASIS FORMATION OF SPIRITUALITY
}

\author{
Natalia Bilchuk \\ National Aerospace University "Kharkiv Aviation Institute", \\ Faculty of Humanities and Law, \\ Department of Philosophy and Social Sciences \\ Chkalova str., 17, 61070, Kharkiv, Ukraine \\ Liudmyla Kolotova \\ National Aerospace University "Kharkiv Aviation Institute", \\ Faculty of Humanities and Law, \\ Department of Philosophy and Social Sciences \\ Chkalova str., 17, 61070, Kharkiv, Ukraine
}

For more than half a century, discussions have been going on about the prospects for further human development in a world of "groundlessness". According to this theory the world has lost its clearness, in the new conditions "all identities are only simulated", and with the "death of God" the world had lost order, fundamentality, beauty, harmony, mystery... Researchers loudly proclaim that the main global problem of the modern world is the collapse of its anthropological foundations, the crisis of spirituality.

In the history of self-actualization of the mankind, many systems of philosophy were created. Some of them explained the concept of spirituality, filling its content with such essential features that most accurately reflect the peculiarities of understanding of the inner world of the person. Ukrainian philosophers created the "philosophy of the heart" that reflects the uniqueness of the Ukrainian mentality (worldview). They considered "heart" as the concentration of the spiritual and mental being of personality. The methodological principles that were stated by P. Yurkevich in the "philosophy of the heart" make it possible to use the "heart" notion as a concept of philosophical discourse to analyze anthropological problems, in particular, spirituality.

The starting point of the article was the idea that the world is not Being, an "objective reality", something given to us, into what a person is included as a component. It is rather an "existential project" created jointly and individually, something that is constantly in the process of creation. Due to the use of the "heart" concept, inner "world-building" is caused by sensory-emotional, activity-volitional and moral-ethical categories. They determine the subjectivity of views of the world, unique personal position. In other words, they determine the creation of their own life-space, that "text" (according to postmodern terms), in which the "personal I project" can be realized. That's why in this research the main focus was on interpretation of "heart" as the basis of the person's spirituality. There is a difference between the concept of "soul" and the concept of "spirit" and "spirituality". While the concept of "soul" (with the "heart" as a main point) is associated with the finiteness and expressiveness of the individual essence of man, the concept of "spirit" and «spirituality"focuses on the infinity and mysterious depth of man's inner world, connecting with the super-individual and metaphysical-subjective basis of his existence. At the same time, there are categories that combine the concepts of "heart" and "spirituality". For example, categories of memory, eternal moral principles, love, and conscience determine the interconnection of subjective and objective, individual and universal, naturally finite existence and essential constant "transcendence" (M. Heidegger) of man beyond the existing. They also determine the principles of forming a personal life project. Thus, the concept of "heart" enriches the understanding of spirituality. Besides, explaining of its essential content helps to form such world where a man can be created.

Key words: spirituality, "heart", "heartiness", "individual text".

(C) N. Bilchuk, L. Kolotova, 2021 
The current state of mankind development could be characterized as a general crisis that encompasses all structural components of social life. The changes that are taking place in socio-political and cultural life are global and globalizing. Those changes involve society as a whole and each person as well. Modern people have already faced with the restructuring of the society infrastructure, the increase and instability of social ties and groups. All these force us to rethink the essential and fundamental problems of human and world existence again and again and to pay attention to the consideration of moral and value bases of individual and social life [1, p. 35].

For more than half a century, discussions have been going on about the prospects for further human development in a world of "groundlessness". According to this theory the world has lost its clearness, in the new conditions "all identities are only simulated", and with the "death of God" the world had lost order, fundamentality, beauty, harmony, mystery... Researchers loudly proclaim that the main global problem of the modern world is the collapse of its anthropological foundations, the crisis of spirituality. "I have a feeling," writes the "Georgian Socrates" Merab Mamardashvilli, "that among many catastrophes that the 20th century is famous for and threatens us with, one of the main and often hidden from the eyes is an anthropological catastrophe..." To his mind this catastrophe isn't manifested in such exotic events as collision of the Earth with an asteroid, or in the depletion of natural resources, excessive population growth, and an environmental or nuclear tragedy. He means an event that happens to a person himself because of destruction or simply the absence of civilized foundations of the life process. From Mamardashvilli's point of view something vital can irreversibly break down in each person [2]. Therefore, the most essential and important problem of our time is overcoming the crisis of spirituality.

In the history of self-actualization of the mankind, many systems of philosophy were created. Some of them explained the concept of spirituality, filling its content with such essential features that most accurately reflect the peculiarities of understanding of the inner world of the person. Among the features that shows the specificity and uniqueness of the Ukrainian mentality (worldview), cardiocentricity and existentialism of thinking are especially highlighted. They found their theoretical reflection in the "philosophy of the heart" created by Ukrainian philosophers. They considered "heart" as the concentration of the spiritual (noumenal) and mental (phenomenal) being of personality [3, p. 206]. The methodological principles that were stated by P. Yurkevich in the "philosophy of the heart" make it possible to use the "heart" notion as a concept of philosophical discourse to analyze anthropological problems, in particular, spirituality. As it was noted by the famous Ukrainian philosopher S. Krymsky, spirituality is not a definite construct. It is rather the way to yourself. It's a kind of lifetime's journey for the person... Spirituality is a process and a result of the value building of the person. This is almost endless path to the formation of his inner world, that allows the person NOT to depend entirely on the external life and to remain identical to himself $[4$, p. 12]. Thus, the understanding of spirituality and explaining of its essential content helps to form such world where a man can be created.

The purpose of this article is to explain the existential-personalistic world concept in Ukrainian philosophy through the genesis of the philosophical notion of "heart". This world concept is most vividly presented in the theories of G. Skovoroda and P. Yurkevich. These authors presented the "heart" concept as the notion of philosophical reflection and explained its conceptual content for the analysis of spirituality.

Any attempt to formulate a different, specific "understanding" of the world begins with a search for a metaphor. It can later grow into the notion of philosophical reflection, and in special cases, become a concept, i.e. an idea with innovative content. So, since antiquity, the image of the "heart" has been used to express such characteristics of a man's inner world that go beyond the limits of his rational discursive abilities - the sensory-emotional and active-volitional charac- 
teristics of a person. Thus, a tradition has developed to explain the essence of man, his inner world with the help of two opposite principles: "mind" and "heart". In the Christian tradition, the "heart" personifies the spiritual component of the human world, its proximity (similarity) and aspiration for the divinity. For the first time in the Western European tradition, "heart" becomes the concept of philosophical reflection in the Pascal's theory. He emphasized that in the field of cognition of human existence, "the laws of reason" and "laws of the heart" do not coincide and "one should not wait for the understanding of the laws of others". And only in Ukrainian philosophy "heart" becomes a concept that describes not only individual and unique man's being, but also sacred and spiritual being of a person that can't be expressed in terms.

The formation of Ukrainian philosophy took place under the significant influence of Christianity of the Byzantine type, which allowed, on the one hand, not to lose touch with the Western European tradition, and on the other, gave an existential-anthropological orientation to philosophical searches. The understanding of the fundamental discrepancy between the external, manifested world and its internal, hidden essence is characteristic of Ukrainian philosophy. It makes more important and difficult the search for such foundations that could give stability to a person in a constantly changing world. At the same time, the existential understanding of philosophy as Sophia, the Wisdom of God, focuses on the search for a unique solution to the problem of the relationship between the essence and existence of man, spirituality and soulfulness. It is not the mind, but the "heart" becomes fundamentally important in explaining the inner world of a person. That's why the "heart" became the central theme of the existential searches of Ukrainian thinkers. Its main task was to explain the essence of a person's inner world and its relationship with the outer world.

The Christian tradition of the Byzantine type (first of all we mean hesychasm) became a grounding of Ukrainian worldview features. The doctrine of Divine energy, which as an active principle is the Deed and the eternal essence of God, the idea of the Transfiguration and Deification of man in the process of dialogical communication, the idea of holism, understanding of the "heart" as the energetic-existential center of man (kind of entelechia), accentuates the existential-anthropological nature of Ukrainian thought. For example, G. Skovoroda defends the position of the fundamental discrepancy between the external world and its hidden essence. In order to explain this he created the doctrine of "three worlds" and "two natures". At the same time, the non-coincidence of these worlds does not mean their opposition. Based on the dialectical understanding of the world, developed by the Byzantine patrists and hesychasts, G. Skovoroda presents the world as a single integral organism, where the central place is given to Sophia. By the Skovoroda doctrine, Sophia is the Wisdom of God, which, like Divine energy, is invisibly present in everything, uniting worlds and conditioning the integrity and teleology of being. It should be noted that the "sophianic" understanding of the world in the Ukrainian tradition focuses, first of all, on anthropological issues. It analyzes the sensory-emotional, moral-evaluative attitude to the world, the individual and unique spiritual essence of man and the basis of his integrity. In the Ukrainian tradition, Sophia is rather identical to the feminine image of Philosophy as philosophizing, worldly wisdom. In other words, the focus is not on knowledge itself, but on aspiration for it, being on the way and evaluative attitude, love. Therefore, in the anthropological aspect, Sophia is revealed through self-knowledge, sensory-emotional, "heart" understanding of the world and the fundamental principles of its harmonious existence. Thus, an existential understanding of the world is being formed in Ukrainian philosophy. The world is not Being, an "objective reality", something given to us, into what a person is included as a component. It is rather an "existential project" created jointly and individually, something that is constantly in the process of creation. Its construction is based not on certain (given by authorities or tradition) 
ideas about moral values, ethical norms, rules of behavior, but on the emotional and evaluative formation of the world of a person and a whole society at the same time. This is what S. Krymsky had in mind when he said that spirituality is a person's life, a search for oneself. This is what the outstanding Ukrainian philosopher M. Popovich had in mind when he pointed out that nothing definite can be said about a person while he/she is alive. The same thing said the outstanding German philosopher L. Feuerbach: "If you want to know who I am, wait until I die".

An original philosophical doctrine of the spiritual foundations of the unique personality's world is presented in the theory of Pamphil Yurkevich. The result of his research was the creation of the "philosophy of the heart" as a theoretically grounded philosophical doctrine, in which the "heart" is presented as the metaphysical center of the inner world of a man. According to this theory the "heart" is the basis of spirituality and morality, man's cognitive, evaluative and volitional activity. The central theme of all the works of Yurkevich is the desire to explain the inner world of a person as an individually unique integrity that harmoniously combines spiritual aspirations and emotional manifestations, taking into account the peculiarities of the national mentality.

The whole philosophy of P. Yurkevich is aimed at finding a basis for the dialectical unity of the opposites discovered by Western European rationalism. P. Yurkevich completely disagrees with R. Descartes and the Cartesians, who believed that objective knowledge about the subject is the only one. Thinking of rational knowledge as the only way to understand the world and a man determines the disintegration of being at all its levels, and deprives the person of individuality and uniqueness [5, p. 89]. P. Yurkevich insists on principle that the world and man are not limited to their external manifestation, are not open and transparent for discursive thinking. The rationalistic approach always leads to a contradiction between essence and phenomenon in all aspects of being. Talking about man in this way shows the opposition of the spiritual and mental, essential and manifested, individual and social, theoretical and practical, etc. Having the principles of anthropocentrism as a background, P. Yurkevich sees the possibility of removing these contradictions with the help of the metaphysical basis of the integrity of the inner world of a person in the person himself, using the "heart" concept. Based on the Bible concept of the world, man and methodological fullness of the "heart" symbol, the doctrines of the Byzantine Cappadocians and Hesychasts, the G. Skovoroda theories and the achievements of Western European thought, P. Yurkevich presents "heart" as a concept of philosophical reflection. The analysis of the "heart" doctrine made it possible to represent it as a metaphysical foundation for the integrity of the inner world of a man and the harmony of his relationship with the surroundings. The "heart" is seen as the center of all feelings and aspirations, the concentration of the initial moral principles, the source of the soulful and spiritual world of a person. The mental, spiritual, essential aspects of the inner world of a person are not identical. At the same time they do not oppose each other, they have a single basis.

In the works of philosophers, the concept of "heart" usually aims to consider (define) the inner individual-unique essence of man, which in its depth always remains uncertain, hidden, especially from himself. At the same time, the inner, mysteriously incomprehensible world of the human essence is manifested through the outwardly revealed abilities and properties of man. Due to the use of the "heart" concept, such "world-building" is caused by sensory-emotional, activity-volitional and moral-ethical categories. They determine the subjectivity of views of the world, unique personal position. In other words, they determine the creation of their own life-space, that "text" (according to postmodern terms), in which the "personal I project" can be realized. That's why in this research the main focus was on interpretation of "heart" as the basis of the person's spirituality. There is a difference between the concept of "soul" and the concept of "spirit" and "spirituality". While the concept of "soul" (with the "heart" as a main point) 
is associated with the finiteness and expressiveness of the individual essence of man, the concept of "spirit" and "spirituality" focuses on the infinity and mysterious depth of man's inner world, connecting with the super-individual and metaphysical-subjective basis of his existence. At the same time, there are categories that combine the concepts of "heart" and "spirituality". For example, categories of memory, eternal moral principles, love, conscience determine the interconnection of subjective and objective, individual and universal, naturally finite existence and essential constant "transcendence" (M. Heidegger) of man beyond the existing. They also determine the principles of forming a personal life project.

Thus, the ideas of Ukrainian philosophical thought, embedded in the distinctive (original) "heart" perception and formulated in the "philosophy of the heart" fully correspond to the spiritual challenges of our time. The basis of the uniqueness ("individual text") of a person is the metaphysical basis of his spirituality - "heart" as the focus of the sensory-emotional, moral-ethical, individual-social, cognitive-axiological foundations of his being. The fundamental unknowability of the "heart" also indicates the indeterminacy of these metaphysical foundations (after all, any "identity" is only a simulation). In turn, this aims at the need to search for and define one's own spiritual foundations, principles that allow us to form the living space of each person. Spirituality is a value structure of personality, the renewal of which will allow us to overcome the most global (deepest) crisis of our time - the loss of humanity.

\section{References}

1. Shyroka S. Value management as a phenomenon of moral culture: perspectives of research. Humanities journal, 2019. № 1. P. 35-45

2. Мамардашвили М. Сознание и цивилизация. URL: http://psylib.org.ua/books/_mamar02. htm

3. Більчук НЛ. Кордоцентризм як принцип цілісного розуміння людини. Інтелект. Особистість. Цивілізація : збірник наук. праць. 2011. С. 201-207.

4. Кримський С. Заклики духовності XXI століття. Київ : Видавничий дім «КМ Академія», 2003. $32 \mathrm{c.}$

5. Юркевич П.Д. Сердце и его значение в духовной жизни человека, по учению слова Божия. Философские произведения. Москва, 1990. С. 69-103. 


\title{
«СЕРЦЕ» ЯК ЗАСАДА ФОРМУВАННЯ ДУХОВНОСТІ
}

\author{
Наталя Більчук \\ Начіональний аерокосмічний університет імені М. С. Жуковського \\ «Харківський авіаційний інститут», \\ гуманітарно-правовий факультет, \\ кафедра філософії та суспільних наук \\ вул. Чкалова, 17, 61070, м. Харків, Україна \\ Людмила Колотова \\ Національний аерокосмічний університет імені М. С. Жуковського \\ «Харківський авіачійний інститут», \\ гуманітарно-правовий факультет, \\ кафедра філософії та суспільних наук \\ вул. Чкалова, 17, 61070, м. Харків, Україна
}

Вже понад півстоліття не вщухають дискусії про перспективи подальшого розвитку людини у світі, який втратив визначеність, в якому «усі тотожності тільки зсимульовані» і який зі «смертю Бога» позбавився впорядкованості, фундаментальності, грунтовності, краси, таємничості... Дослідники на всі голоси проголошують, що головною глобальною проблемою сучасного світу $є$ крах його антропологічних засад, криза духовності.

В історії розвитку самосвідомості людства було створено безліч філософських теорій, в яких звертались до поняття духовності, наповнюючи його зміст такими сутнісними рисами, які в найкращий спосіб відображають особливості розуміння внутрішнього світу самої людини. Специфікою вирішення цих проблем в українській філософській думці стали «сердечність» як спосіб світосприйняття та понятійне визначення «серця» як метафізичного центру внутрішнього світу людини. В украінській філософії образ-метафора «серце» перетворюється на поняття філософської рефлексії, яке розкриває не тільки індивідуально-неповторні властивості людини, але й насамперед невимовний у дискурсивних поняттях сакрально-духовний світ людського буття. Методологічні принципи, закладені П. Юркевичем у «філософії серця», дають змогу використовувати поняття «серце» як концепт філософського дискурсу для аналізу антропологічних проблем, зокрема духовності. Вихідною засадою статті стало те, що світ не є даність, в яку включається і людина, а розглядається як «екзистенційний проєкт», який здійснюється як індивідуально, так і спільно.

Завдяки використанню поняття «серце» таке «світовибудування» зумовлене чуттєво-емоційними, діяльно-вольовими і морально-етичними категоріями, які визначають суб'єктивність поглядів на світ, унікально-особистісне до нього ставлення. Зосереджені в понятті «серце» категорії «пам’ять», «моральні цінності», «любов», «совість», що становлять духовність, зумовлюють взаємозв'язок індивідуального та загальнолюдського, природно скінченого існування і постійного сутнісного становлення людини, визначаючи засади формування особистісного життєвого проєкту. Таким чином, поняття «серце» збагачує розуміння духовності, а розкриття їхнього сутнісного змісту може стати тим знаряддям, завдяки якому створюється індивідуальний «світ-текст», в якому тільки і може відтворювати свою екзистенцію людина.

Ключові слова: духовність, «серце», «сердечність», «індивідуальний текст». 